\title{
Whistle-stop guided tour
}

THIs page provides a map, both geographic and institutional, of science in Brazil. As with any map, its principal appeal is to people who dislike travelling without always knowing exactly where they are. Those who are content simply to arrive may turn to the following pages.

Universitles. Brazil has more than a million students enrolled at its federal, state and private universities, but there are only eight universities carrying out active research in a wide range of scientific disciplines.

In a category of its own, well ahead of any competitor, is the University of São Paulo (page 368 ). It produces more than half the doctorates in Brazil. Second comes the University of Campinas (UNICAMP), located 100 kilometres north of São Paulo (page 368). USP and UNICAMP are not supported by the federal government but by São Paulo state which is Brazil's richest, generating 50 per cent of total gross national product (GNP).

Third is the best of the federal universities, the Federal University of Rio de Janeiro (page 358). After Rio, the rankings are open to dispute (and, of course, any university may have particular specialities in which it excels). But most agree that in the next five places will be the Pontifical Catholic University of Rio de Janeiro (remarkable as the only private university with strength in science, page 359), the State University of São Paulo (yet another of São Paulo's state-funded universities, with campuses throughout the state), the Federal University of San Carlos (again located in Sâo Paulo state), the Federal University of Rio Grande do Sul (located in Porte Allegre in Brazil's southernmost state), the University of Brasilia, and the Federal University of Minas Gerais (located in the state capital of Belo

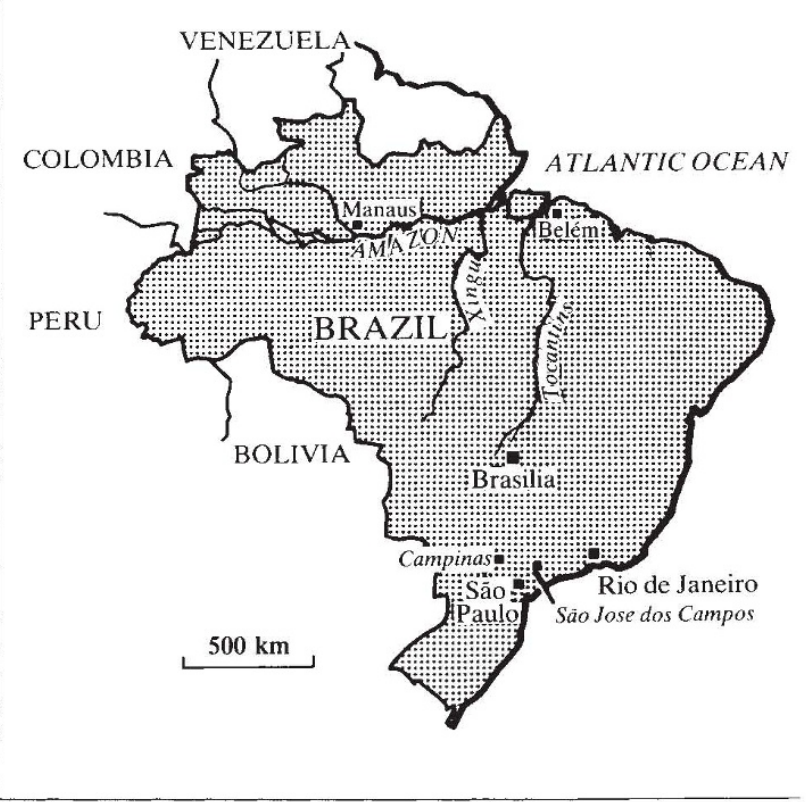

Horizonte).

Research institutes. At one time or another, all of the major research institutes belonged to what everyone still knows as the National Research Council and refers to as "CNPq". (The council's change of name to the National Council for Scientific and Technological Development has proved unpopular, page 373 ). Eleven research institutes still belong to $\mathrm{CNPq}$; for historical reasons they are concentrated in Rio de Janeiro. Two major research institutes, for space research and amazonian research, are now attached directly to the what most people refer to as the Ministry of Science and Technology. In fact, the name is not correct. In a dramatic political battle, the ministry was absorbed by another ministry early this year but fought its way out again, victorious and independent, as the Special Secretariat for Science and Technology of the President of the Republic (page 371) a ministry except in name. The research council, $\mathrm{CNPq}$, is answerable to this body.

There are many other research institutes - for Meteorology, Metrology, Mining and so on - attached to other ministries but they are less central to Nature's interests. Exceptions are the Oswaldo Cruz Foundation of the Ministry of Health, and the EMBRAPA chain of research institutes attached to the Ministry of Agriculture (pages 370 and 363).

Research support. Virtually all support for scientific research comes from the government. The total budget in 1987, the last year for which complete figures are available, came to $\$ 1,640$ million, approximately 0.7 per cent of GNP. The following year the budget rose but in January 1989 massive cuts were ordered by the President. As supplementary budgets are still being debated by Congress it is not possible to say accurately how much will be spent this year, although the final figure could be as low as half that granted in 1987. In that year the budget was divided up among ministries as shown in the pie-chart below, with the Ministry of Science and Technology receiving $\$ 470$ million (35 per cent of the total). Of that $\$ 470$ million, just over half $(\$ 249$ million) went to $\mathrm{CNPq}$ to support its scholarships, research grants and institutions (page 373). Thirty per cent went to the Agency for Financing Funds and Projects (FINEP), which is part grant agency and part
Major research institutes

CNPq

Rio de Janeiro

National Observatory (p.359)

Museum of Astronomy and Related Sciences

National Laboratory for Astrophysics (p.374)

Brazilian Center for Research in Physics (p.361)

Institute of Pure and Applied Mathematics National Laboratory of Scientific Computing Center for Mineral Technology

Belém

Emílio Goeldi Museum (p.363)

Campinas (SP)

National Synchrotron Light Laboratory (p.368) Brasília

Brazilian Institute for Scientific and Technical Information

Centre of Science and Technology Policy Studies

Speclal Secretariat (MInistry of Sclence and

Technology)

São Jose dos Campos (SP)

National Space Research Institute (p.367)

Manaus

National Institute for Amazonian Research (p.362)

\section{Ministry of Health}

Rio de Janeiro

Oswaldo Cruz Foundation (p.370).

commercial bank (page 372 ), and to two other ministry funds, the National Fund for Scientific and Technological Development (FNDCT) and the Programme of Support for Scientific and Technological Development (PADCT). The latter is particularly important because it is through this fund that the World Bank has made a $\$ 72$ million matching loan to Brazil to help in the development of the science base (page 372).

Outside of the Ministry for Science and Technology, support for basic research

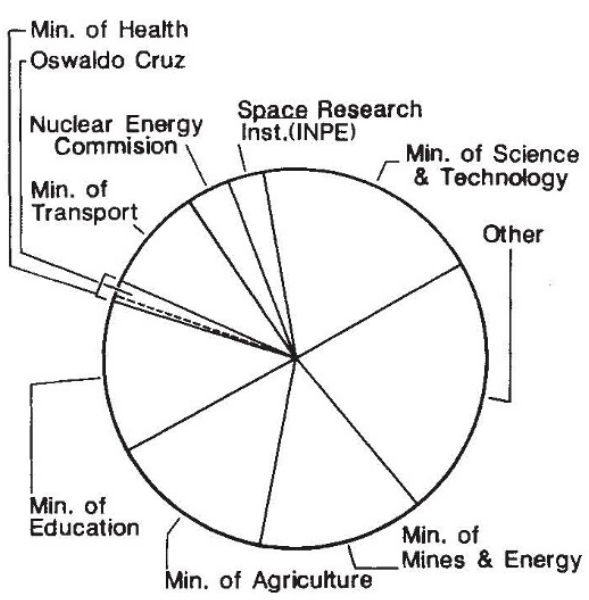

The distribution of government research spending by ministry during 1987 .

comes from the Ministry of Education's Coordinating Agency for Advanced Training of High Level Personnel (CAPES), which supports graduate training in the universities (page 372). Individual states also have their own funding agencies, São Paulo's FAPESP is the best known and biggest (page 372). 